\title{
政 VERSITA
}

ANVIL 29 (1) September 2013

DOI: $10.2478 /$ anv-2013-0009

\section{Reviews of books published before 2011}

This second article of reviews tackles books published before 2011. Although they cannot really be described as very recent publications, they are all still quite recent and on the whole deserve the publicity and attention that reviews afford.

Tom Wilson, Anvil Book Reviews Editor

\section{1) Biblical Studies}

Elisabeth Goddard and Clare Hendy. The Gender Agenda - Discovering God's plan for church leadership. (IVP, 2010)

Whenever I find myself leading seminars looking at areas of biblical theology where evangelicals come to different conclusions, I always begin by reminding students of a simple maxim. That maxim is that the position they are already familiar with will appear self-evident to them as we look together through the different Bible texts.

Of course, such a lack of objectivity does not apply to those of us in theological education, and I finished reading The Gender Agenda telling myself that one half was brilliantly reasoned biblical exegesis, and the other half needed a lot more work...

The Gender Agenda is written to fill the significant gap in the crowded market of books about women in leadership. In the wider debates about women in church leadership, it is vital to recognise one's own starting position and assumptions and this book aims to present and engage with the strongest biblical arguments for both a complementarian and egalitarian view of men and women in church leadership. This is an aim which Lis Goddard and Clare Hendry ably achieve as we follow their e-mail correspondence over several months and they take time to exegete, understand and apply all the relevant passages. Their writing avoids the unhelpful rhetoric and accusations which often accompany this debate and they also do not divert our attention away from the Bible with the sub-biblical arguments and lines of enquiry which both sides of debate often resort to. 
A secondary aim of the authors is to model gracious debate between Christians about this sort of issue. The tone of the e-mails between Lis and Clare reveals a genuine friendship which is not defined by their respective views on the issue, and both authors recognise that the other holds their position with integrity and based on serious study of the Bible. This may have been made easier as neither Lis nor Clare appear to occupy very extreme positions within their respective viewpoints. This may lead readers of all viewpoints to think that the arguments do not try hard enough to convince the reader of their view.

A weakness of the exchanges, however, is that neither of the authors appears to have allowed the other, or the debate, to shape their own understanding. It seems that the position which was self-evident to them at the outset remains to be so, sometimes even in the face of very strong exegetical evidence. The result is a lack of synthesis as agreements are presented and refuted rather than developed and honed. Both authors spent considerable time in Oxford University and, rather like members of the Oxford Union debating society, the reader is left here to vote for whichever of these well-argued positions they feel is the most convincing at the end of the day. This means that readers are likely to have their initial view confirmed, rather than challenged and honed by engaging with this book.

The Gender Agenda comes into its own is where students, pastors or church members are looking for a single, balanced, source of faithful exposition which takes seriously the biblical texts relevant to women in church leadership. I am often approached by students who say 'I don't know what to think about this' or 'what does the Bible really say about this'. I am confident to recommend The Gender Agenda as a primer which will take them into the Bible, without imposing my own view before they have thought about theirs.

Jon Marlow, Dean of Studies, Peninsular Gospel Partnership, Plymouth

\section{Ben Witherington III. Imminent Domain: The Story of the Kingdom and its Celebration. (Eerdmans, 2009)}

Witherington argues in this slim volume that the Kingdom season is somewhat neglected in the church's liturgical year, and suggests this may be for theological reasons, such as a lack of clarity over when the Kingdom appears, (already or in the future?), and a muddle over terms such as 'Church, 'Kingdom' and 'Israel'. He seeks to shed light on such issues and does so with familiar but scripturally robust reasoning.

Throughout Witherington prefers "Dominion" to "Kingdom" since the former can refer to an activity or condition as much as a place, and this is truer to the multi-dimensional meaning of 
the original terms in Greek and Aramaic. He understands this Dominion to be a cipher for God's final divine saving activity, manifest in Jesus and then echoing in his followers down to the present time. As such God's Dominion can be distinguished from the Church (which bears witness to and seeks to manifest this Kingdom in its life and service) and from Israel (to whom God's promises will be fulfilled - but in Christ and not apart from Christ).

Witherington argues that the Dominion is present, being manifested in Christian lives and loving character, as well as being evidenced by the church recognising and living under the sovereignty of God (in worship for example). However the Dominion is also to come, in its final and complete form, with the return of Christ, the resurrection of the dead and the transformation of this world and cosmos to a new heaven and earth where God is all in all. This is an accessible and concise introduction to the theme of the Kingdom of God, and the six chapters might easily form the structure for a weekly course on the Kingdom for small groups, given the questions for reflection and discussion at the end of each chapter.

Mike Harrison, Leicester

\section{2) New Testament Studies}

Gary M. Burge. Jesus and the Land: How the New Testament transformed 'holy land' theology. (SPCK, 2010)

There is arguably no debate in the world today as divisive or intractable as Israel and Palestine, and it is also highly theological. Despite modern Israel's secular trappings, the nation bases its land claim to Palestine on the Old Testament biblical text, which is, arguably, inseparable from notions of divine promise. At the same time American Christian Zionism insists that full support of Israel is every Christian's religious duty; to do otherwise is to risk God's disfavour and delay the otherwise imminent apocalypse. In response to this crisis Gary Burge offers Jesus and the Land, a fairly brief account of the biblical relationship to the land and how, according to Burge, it is fundamentally subverted by the gospel of Jesus. For Burge, the desire to align religion and land is a natural instinct that is not altogether bad; humans live on land and apply great meaning to the places they inhabit. However, problems arise when divine promise and tribal claims to land are fused and the ethnic (racial) 'other' is necessarily demonised in the process. To this distinctly Jewish problem (Burge makes little effort to understand positive manifestations of Jewish familial identity) comes Jesus, whose Gospel heralds a new and better age of the Jewish covenant. An age that transcends the material, landed and fleshly qualities to previously define Jewish identity in the service of opening the 
covenant to all peoples of all nations. Regarding the modern crises, Burge contends that a proper and properly Christian response (Burge's transcendent Christian ethics seems to only apply to Christians) is geographic disinterest owing to Christ's universalising work. Indeed, with Christ's work on the Cross, any religious significance attributed to the land has been 'fulfilled' and thus nullified in the man Jesus; a Christian then, while still always belonging to a particular nation and heritage, is properly above national and ethnic divisions and, when presented with the perpetual strife in the region, should offer indiscriminate compassion to all.

One's enjoyment of Jesus and the Land will largely depend on where you stand on the IsraelPalestine debate, this is no criticism but an admission that the biblical theology Burge employs can no longer be politically neutral. Should the reader side with Israel they will find ample biblical and theological resources to support this, and not all of it will be Christian Zionist. Burge, on the other hand, is firmly siding with the Palestinian plight and he accomplishes this by wielding some very old theological weapons indeed. Those who've read Ruether's Faith and Fratricide or are familiar with patristic anti-Jewish literature will appreciate that Burge's Jesus is great to the extent that he spiritualises Jewish flesh, universalises the particular Jewish people and transcendentalises the land, meaning that three fundamental Jewish attributes are nullified. Burge wishes to categorically state, however, that despite this fundamental religious overhaul, this Jesus (and the larger New Testament) is not anti-Jewish and does not replace the old law but "fulfils" it as the consummation of Abraham's universal inheritance. The question is whether this is a convincing or responsible theology in the age of Jewish-Christian relations and where affirming Christian identity at the expense of the Jewish is no longer pure theology but a statement with philosophical, political and bloody baggage. Burge's thesis rests on whether Jesus could be said to have made the Jewish people redundant, but Burge's arguments boil down to the same tired religious caricatures that see Jesus' mission on earth in terms of his gracious universalism versus the inherently legalistic Jewish provincialism, in the form of their exclusive claim over a certain stretch of land.

A highlight of the book is a discussion of pre-Christian Jewish Diaspora living, however, instead of this being an opportunity to explore another feature of Jewish life (Jeremiah 29:7 the richest example), Burge treats it as a foretaste to Christian universalism and, in turn, authentic (Christian) spirituality breaking free of myopic (Jewish) strictures. Despite these serious criticisms, Burge's book is a solid and consistent reworking of patristic orthodoxy 
onto modern political theology, and those that still adhere to this account of Christian identity will find much to base a stance on. For others, those who've grown uncomfortable with Christian theology's anti-Jewish instincts, Burge's thesis is just another, albeit more politely phrased, account of the Christian Church's rejection of the Jewish people and their landed attribute.

William Evans, Birmingham

\section{Terence L. Donaldson. Jews and Anti-Judaism in the New Testament: Decision Points and Divergent Interpretations. (SPCK, 2010)}

Of all the upheavals to affect post-war Christianity, perhaps none has been more disturbing than the recognition that traditional Christian theology was ideologically complicit in the holocaust. Coupled with the begrudging admission that Jesus was a devout Jew, the church has been slow to come to terms with a New Testament that has proven so effective in discriminating against the Jewish people. In the early days of the debate, the New Testament was presented as largely anti-Semitic and stripped of its holy significance. Liberal exegetes soon offered a picture of the Judaeo-Christian schism figuring Christianity's universalising instincts as incompatible with Jewish particularism; such a model paints Paul as the key player in defining Christianity as non-Jewish (a model thoroughly neutralised by the New Perspective) and sees anti-Jewishness as built into the fabric of Christian identity. In time however a more complex image would emerge of a thoroughly Jewish early church and a gradual (and multiple) sheering of movements that would result in two religious traditions. In this reading the so-called anti-Jewish verses only appear to be hateful because Christians read them outside of their proper context of an internal Jewish debate, which would naturally include fierce polemic but still maintain the essential goodness of "Jewishness" and its enduring covenant.

Every one of these competing theses, and I mention only few, rests upon a very specific account of the social, political, and religious context of the New Testament text. However, the great variety of uncertainty within NT scholarship is often glossed over for the sake of theological stability and, in the case of alleged anti-Judaism, the church's ever-contentious position towards the Jewish people. To attempt to make sense of how contextual ambiguities dictate vastly different interpretations of alleged New Testament anti-Judaism, Terence L. Donaldson's study delicately examines exactly how varying contexts can produce, on the one hand, innocuous inter-Jewish squabbling and, on the other, hateful anti-Semitism. Donaldson 
employs three criteria to explore textual context, self-definition, social location, and rhetorical function, through which several historical perspectives and their accompanying conclusions are discussed. And indeed this is a discussion, no normative historical interpretations are offered nor any solutions to NT anti-Judaism; Donaldson's intent, which he surely achieves, is to map the multiplicity of interpretations and the historical conclusions that must be drawn from them and offer suggestions about methodology.

Donaldson has done a fine job tracking the many lines of interpretation and his three criteria elucidate a subject often mired in political baggage. His study will be useful for scholars and laymen alike wanting clarity on this highly divisive subject. However, as I mentioned, Donaldson's treatment is strictly concerned with clarifying the contours of the debate, not offering a 'solution'. As such, those seeking to make a decision will be frustrated by Donaldson's unwillingness to espouse a single reading of the New Testament's account of the Jews; however, those seeking to understand this, perhaps un-solvable, puzzle will be enriched by Donaldson's thoughtful and rigorous treatment.

William Evans, Birmingham

Mark D. Given. Paul Unbound: Other Perspectives on the Apostle. (Hendrikson, 2010) This collection of essays had its genesis in a 2004 Central States SBL meeting in St Louis. It is intended to provide fresh insight on the Apostle Paul, in particular perspectives other than those dominant in NT studies (namely the 'New Perspective'). Paul Unbound is a useful library resource, but not really a book to read in its entirety in one sitting. The essays are written by experts in their fields, but do not really advance those fields; rather they provide useful orientation and bibliographic resources for students wishing to investigate things further for themselves. As such they are all open to criticism for what they choose to omit or how they summarise a particular scholar's approach to a given topic. But any introduction of necessity provides only a small sample of the field. The essays are all interesting and accessibly written and will be useful to students in need of introduction to their respective fields.

Tom Wilson, Gloucester

\section{Keith Warrington. Discovering Jesus in the New Testament. (Hendrikson, 2009)}

This is an accessible introductory level work, covering some of the main Christological ground in the New Testament. It is probably overly driven by Christological titles and suffers 
from treating the Synoptics in a single chapter. In his introduction, Warrington states his intention to concentrate on Jesus' identity not his ministry, 'on who he is not what he did.' But as he himself admits, Christology is as much about actions as words; Jesus did what he did because of who he is. Presumably limitations of space forced Warrington into a pragmatic choice, but the result is a greatly diminished book. This means it would not be my first choice recommendation for an academic treatment of New Testament Christology. It is an easy read, provides some helpful pointers for the inexperienced reader and would be of benefit to such a lay audience. For those who want to dip their toes into the deep waters of New Testament Christology, this is a useful start; but you would be better to go elsewhere if you wished to engage in deeper swimming.

Tom Wilson, Gloucester

\section{3) Doctrine and Philosophy}

\section{Paul Copan and Chad Meister. Philosophy of Religion: Classic and Contemporary Issues.} (Blackwell, 2008).

This volume of essays by a range of leading thinkers provides a valuable insight into the current of 'state of play' in the major debates in the philosophy of religion. The book is divided into four parts, entitled: Religious Experience and Knowledge; The Existence of God; The Nature and Attributes of God; and Emerging Themes. Each part includes a handful of essays offering competing perspectives on these central topics.

Part I, on religious knowledge, includes essays on religious experience, religion and science and Reformed epistemology. Competing chapters by Joseph Runzo and Harold Netland argue for religious pluralism and religious exclusivism respectively. Runzo (following John Hick and others) sees an 'axiological consensus' amongst all the major faiths which recognises a common basic morality, a mutual respect for human rights and a shared recognition that "the source of meaning in life is relationship to a Transcendant" [63]. Netland, in contrast, suggests that there is no such 'epistemic parity' between religions. Some faiths, notably Christianity, have much stronger epistemic support than others, since their central beliefs are more logically coherent and evidentially justified.

Part II brings the reader up to date with the latest versions of traditional arguments for the existence of God. William Lane Craig offers a contemporary articulation of the kalam cosmological argument, while Robin Collins argues for a modern version of the teleological argument based on "the fine-tuning of the cosmos for conscious embodied life, and the 
beauty elegance and discoverability of the underlying mathematical order of nature" [108]. Despite falling out of fashion in the twentieth century, Graham Oppy uses his chapter on the ontological argument to argue that many interesting and unresolved questions prevent it being safely dismissed to the dustbin of theological ideas. The contemporary case for atheism, meanwhile, is made in two chapters by Paul Draper and Quentin Smith. Draper adopts a Bayesian probabilistic argument to deduce that, contrary evidence notwithstanding, the existence of evil in the world makes naturalism more probable that theism. In his chapter Smith seeks to counter the cosmological argument for a Creator by offering a 'Naturalistic Account of the Universe'. He contends that contemporary Big Bang cosmology, which posits a unique 'singularity' event at the origin of the cosmos, has established the possibility of a self-caused universe.

Part III of the book wrestles with the coherence of traditional Western conceptions of God. Charles Taliaferro and Robin Le Poidevin, for example, review contemporary debates over the logical possibility of an omniscient, omnipotent and perfect divine being, while Katherin Rogers examines philosophers' most recent efforts to reconcile a sovereign, timeless God with genuine human freedom. A quite moving article by Paul Moser ends this part of the book, arguing that ultimately only faith in God can offer us true meaning and lasting hope in the face of death.

The fourth and final part of this book offers an overview of 'emerging themes' in the philosophy of religion, notably continental, feminist and eastern philosophy, each of which differs in their methods and conclusions from the Anglo-American analytic philosophy with which most of us are more familiar.

Overall, this is a valuable and instructive work. Perhaps not the first place to turn for an introduction to the topic (Brian Davies' book, An Introduction to the Philosophy of Religion, probably remains the best primer on the subject), but certainly an ideal read to get up to speed with the latest thinking on these vital questions of faith and belief.

Phil Weston, Aughton, Liverpool.

\section{George Pattison. Crucifixions and Resurrections of the Image: Christian reflections on art and modernity. (SCM, 2009)}

This collection of essays and talks considers a selection of modern (mostly $20^{\text {th }}$ century) artists and art-works in conversation with the Christian dynamic of crucifixion and resurrection. So for instance in Chapter 2 Pattison examines, among other paintings, Manet's 
"Dead Christ With Angels", underlining how shocking the original exhibition of this painting was in its depiction of "a dead man and nothing more", shorn of sentiment and emotion. In such paintings modernity could be seen being artistically confronted with its presumption of a secular world in which God had died. Or is what Manet depicts here the interiorization of sentiment and feeling to its very lowest threshold of visibility? Pattison connects this with crucifixion where we are shown the divine image in what seems to be its ultimate eclipse. So may it not be that what we take to be nihilism in some modern art is in fact simply iconoclasm? In this way Pattison develops a conversation with artists and their works, questioning them from the Christian narrative of a God of crucifixion and resurrection. In later chapters Pattison expands his engagement to include sculpture, literature and recent films, again with the focus being on how reflections on such art might not entail abandoning God but help renew, sustain and encourage us in the faith that the crucifixions we know may bring us to the resurrections for which we hope.

Pattison's theological erudition coupled with his evident knowledge of modern art and the literature surrounding it make this a read which has fascinating insights throughout, and there are helpful reflections on the likes of Kierkegaard, Heidegger, Schleiermacher and Tillich, as well as light cast on artists as diverse as Rothko, Watts and Gormley. It is inevitably eclectic, and the book shows that looseness of fit between chapters that one might expect of a collection of talks and lectures. Nevertheless, if you are interested in modern art, like your theology with a twist of philosophy and enjoy perceptive cultural commentary, this is one for you.

\section{Mike Harrison, Leicester}

\section{Miroslav Volf. Captive to the Word of God. (Eerdmans, 2010)}

This is a book that I will read again. It is well written, accessible and thoughtful. As I was reading the six essay which comprise the book I had to keep putting it aside, sometimes to think and at other times to pray. My main criticism of Captive to the Word of God is that at 180 pages it was too short; I wanted to continue to engage with Volf long after I closed the book.

The sub-title of the book, "Engaging the Scriptures for Contemporary Theological Reflection" aptly sums up the contents. In six chapters written over a period of sixteen years Volf reflects theologically on a number of issues pertinent to the church in the twenty-first century. 
In the first chapter Volf reflects upon his own practice as a theologian. He argues for a Biblically founded, Biblically literate Christian theology which avoids both literalism and mere historical-critical exegesis. Rather he proposes a "hermeneutic of respect" which works with a provisional presumption that this text is the site of God's self-revelation. Readers will detect the influence of Karl Barth in this programmatic essay.

Chapter two is entitled "Theology for a way of Life" and while for me the weakest part of the collection is still worth reading.

In Chapter Three Volf looks at the relation between Church and culture and bases his reflections on 1 Peter. He argues that the Gospel involves living differently in a social context in such a way that the society is transformed from within. In 1 Peter he sees a model of church which maintains a distinction from its context because the church has an allegiance to a distinctive reality. Volf's conclusion that "(t)o make a difference one must be different" is one that a church struggling to find its way and place in twenty-first century consumer society would do well to take to heart.

For me chapter four, an examination of the Fourth Gospel's supposed dualisms, was the strongest essay in the volume. Volf unpacks how in John dualities are overcome by the selfsacrifice of Christ. He then looks briefly at contemporary pluralism and inclusivism as models for the Church's relationship with wider, non-Christian society. He rejects both of these in favour of John's particularism which presents a particular person as universal saviour.

In chapter five Volf examines 1 John 4:7-12 as the basis for engagement with Islam, arguing that proper engagement with non-Christian traditions should not try to ignore or downplay ideas such as Trinity or the place of Christ as Son of God which are potential areas of contention and misunderstanding. He unpacks his chosen text in dialogue with its treatment by classical authors such as Augustine, Luther and Calvin.

The final chapter is a very timely piece on the church in modern society and takes up the point made by Volf in Work in the Spirit that in Christian thought work has a place beyond the manufacture of 'goods' to be consumed and beyond providing workers with means by which they can consume other goods. Rather the Bible, a voice from outside of contemporary culture, regards work as a fundamental dimension of human life and good in itself.

Captive to the Word of God is a collection of essays that repays thoughtful and prayerful reading. It is a good example of Biblically literate and Biblically founded theology which demonstrates the relevance of the Christian scriptures to the church in the twenty first century 
as it wrestles with its relationship with a society for whom God is marginal and disregarded. I thoroughly recommend it.

Tim Gill, Liverpool

\section{4) Ethics and Pastoral Ministry}

Ken Gibson. Too Much Aid not Enough Help. (Columba Press, 2010)

This important book is a hard one to read. Not just because the subject matter is global poverty or that it reveals the complicity the western world and the aid business have had in making the two-thirds world poorer, but because it is unremitting in its style and content. Ken Gibson is the Executive Director of The Leprosy Mission Ireland. It might seem surprising that the leader of a development agency is daring to write a book that encourages less aid to be given to the poor. But Gibson is writing predominantly about intergovernmental aid (otherwise known as multilateral aid), which represents 96 per cent of all aid that is given. Gibson is careful to distinguish between good aid and bad, citing the Expanded Programme of Immunisation as an example of the former. This programme saw a radical decrease in the number of children dying from preventable diseases and saves around three million lives a year. Gibson's main concern is to challenge the way that western governments, especially that of the US and to a lesser extent the UK, have been using aid payments to their own advantage.

Gibson gives a lot of space to a critique of the Official Development Assistance, (which confusingly is listed as Overseas Development Aid in the glossary). The ODA was established at the end of the Second World War primarily to rehabilitate the devastated European theatre of war. In President Truman's plans the ODA was to help "bring the underdeveloped majority of the world's population to the point of being developed". Perhaps President Nixon summed up the rationale behind the aid programme: "Let us remember that the main point of development aid is not to help other nations but to help ourselves" [87]. Gibson then systematically exposes almost every example of intergovernmental aid as serving the national interests of the donor rather than the best interests of the receivers. The World Bank, the IMF and ODA all come in for heavy criticism. There appear to have been so many strings to the aid that it was a massive form of global manipulation and power politics. Gibson even cites occasions where countries were held to ransom as aid was withheld just as countries faced severe famine and more stringent conditions were placed on the receivers knowing they couldn't refuse as people were literally starving to death. 
The final chapter includes suggestions from Gibson on better ways forward. Suggestions include:

- Redefining aid as "Compensatory Finance" which would involve the West repaying its debt to the rest - this would mean control left westerner donors and instead returned to the countries which received the aid.

- Encouraging protectionism in underdeveloped countries where trade tariffs were introduced to help infant industries.

- Protection of local food markets by stopping the dumping of food developing countries' food surplus in under-developed countries.

- Prioritisation of debt relief.

- Devolution of IMF operations to regional blocks such as the African union.

This book is harrowing reading. It is hard work as there is a plethora of figures and abbreviations. The book does not have a specifically Christian audience in mind despite being written from someone who works from a historically Christian development charity. There is no mention of God, scripture or any explicit theological analysis. You could argue that a Christian worldview is assumed but is this because of the latent borrowed intellectual capital of the legacy of Christendom or because of a deliberate application of Christian values on a global tragedy? It seems impossible to tell from the book itself.

There is no real call to action in the book either - the aim seems to be informing a wider group of people as to the flaws of the majority of intergovernmental aid which may inform the way we engage politically. But sadly I think the harsh truth that this book exposes will not be heard by the wide audience that it deserves as a result of its writing style, narrow focus and lack of application to most readers.

Krish Kandiah, Executive Director: Churches in Mission and England Director for the UK Evangelical Alliance.

\section{David Hein and Charles R Henery (Editors). Spiritual Counsel in the Anglican Tradition. (James Clark, 2010)}

One of my recent mental images in thinking about Anglicanism is that of a man who falls asleep one day, into the kind of suspended animation experienced by Rip van Winkle. On waking he discovers that not only is he married: he has five daughters and four sons. He is filled with excitement, until he spends his first evening with this new family. The squabbling is intense and acrimonious, the atmosphere sulphurous; they are, nonetheless, family... 
The same could be said at the moment of the Anglican Communion. What a family we are, querulous, contentious, constantly arguing about the inheritance. The unexpected emergence of our koinonia means that self-definition is incomplete, universally accepted key texts rare, and the practice of the Anglican way ill-defined.

Themed collections of Anglican thought in any field - if they represent the breadth of the Anglican ethos - echo the same uncertain voice. The best collections reflect the genius of an age [More $\&$ Cross [ $2^{\text {nd }}$ ed] 2008, Anglicanism], or a particular stream within the tradition [Rowell, Stevenson, Williams, 2001, Love's Redeeming Work].

Hein and Henery provide us with a similar work, focusing on the formation of the Christian character. The strength of the book is that the excerpts are arranged in subjects by chapter, and it could easily be used as a companion to daily prayer. Key theological emphases [The Love of God, The Sacramental Life] are accompanied by spiritual disciplines [Prayer, Holy Scripture, A Pilgrim's Journey] and specific areas for focused attention [Money, Friendship, Nightfall].

As befits an American publication, there is a mixture of British and American authors. The selections cover the whole period since the Protestant Reformation, and the balance between the historical and the relatively contemporary is good. Predictably, we find the likes of Andrewes and Donne, William Law, John Keble and Charles Kingsley. Twentieth century writers include CS Lewis, Alex Vidler, Dorothy Sayers. Interestingly, every reader this side of the Atlantic will find new treasures, both American and British.

Evangelical Anglicans are, however, poorly represented, and this was a special disappointment to me. It is good to find Hannah More, but the absence of any $18^{\text {th }}$ or $19^{\text {th }}$ century Evangelical leader is disappointing [Where are Simeon, Romaine, the Venns or Ryle?]. The assumption may be that spiritual direction was done by the more catholic minded among us, but this book is about spiritual counsel. The annals of $18^{\text {th }}$ evangelical revival are rich depositories of such counsel, but not in this collection.

But enough of such narrow criticism! The texts themselves, on which a book such as this must stand or fall, are rich, challenging and rewarding reads for any who take the path of costly discipleship seriously. In that sense, the 'Anglican' in the title is historically interesting but irrelevant. As Anglicans we stand in a remarkably rich tradition of wise guidance and learning which we are glad to share as our little contribution to the disciplines of the Christian way. Let those who will, come; let those who come, read. Those who read will be blessed. 
In the final words of the book, 'For Christians, only God can determine when the Holy City of his fulfilled purposes may be attained. But before it can be attained it must be seen. And the seeing of it will depend upon how high the level is on which our imagination and our desire move.' [Walter Russell Bowie: 160]

Adrian Chatfield, Ridley Hall

Oliver O'Donovan. A Conversation Waiting to Begin: The Churches and the Gay Controversy. (SCM, 2009)

In this little volume Oliver O'Donovan treats homosexuality and the surrounding debate in the Anglican Communion with scholarly rigour and pastoral sensitivity. A Conversation Waiting to Begin consists of seven chapters, previously published in 2006 under the "ironic title" [vii] Sermons on the Subject of the Day on the evangelical Anglican website www.fulcrum-anglican.org.uk. The manuscript version was published in 2009 - though O'Donovan's introduction indicates he was preparing the manuscript before the 2008 Lambeth Conference. Therefore, what the reader holds in her hands is a book that has had a significant and long journey. In places the debate has moved beyond O'Donovan's discussion, which can make it feel one step behind the present. In other places O'Donovan shows himself to have a prophetic voice to which the Church ought to have attended sooner, and could still benefit from hearing now. There is a depth of theological reasoning here that brings fresh pastoral light onto a subject darkened by misunderstanding, accompanied by a call to open discussion. The chapters are short but closely argued, and some knowledge of the various discussions, disagreements, and reports within the Church of England and the wider Anglican Communion would help to keep a handle on the argument. That said there is plenty here for readers of all denominations to think about.

Chapter one, “The Failure of the Liberal Paradigm" is ground clearance. O'Donovan is direct and critical when he discusses the modern turn in Liberal Protestantism from its often constructive or "renewing" [6] potential in its independence from established authorities towards something entrenched in a victim mentality, without the "critical practical reason" [11] of its nineteenth century forebears. The task, according to O'Donovan, for the Church is not a falsely acquired notion of emancipation and justice that fails the gay community by overlooking the particulars of their existence, but rather hermeneutics: the quest to understand and interpret gay feeling, and to ask "what are the patterns of life with which it 
may appropriately clothe itself?" [16]. Hence conversation is important: the thoughts, feelings, and reflexive existential interpretations of gay Christians must be heard by heterosexual Christians, and vice versa, so that interpretation and understanding in the light of the gospel can happen.

The thesis is explored further in chapters 2 and 3, "The Care of the Churches" and "Ethics and Agreement". Taken together they could be considered a commentary on the development of the crisis in the Anglican Communion, and a critique of self-serving voices on both sides of the debate. Chapters 4 and 5 turn attention to the vexed question of biblical authority and interpretation, and hermeneutics. O'Donovan's basic premise, as one might expect from an evangelical, is that scripture has an authority of its own that is derivative of the divine authority. Discerning readers will hear echoes of Karl Barth in these chapters, and of evangelical Barthians like John Webster whose little book on Holy Scripture is cited several times. What is clear from O'Donovan's approach is that reading the Bible is not an easy task, especially where ethics is concerned. Part of the concern here is that we recognize what scripture $i s$, namely the authorised witness to God. So, scripture has a task. With this in mind, the reader of scripture needs discernment to comprehend (1) what a particular text means and (2) how we understand ourselves in relation to it [58-59]. Furthermore, such engagement must be referenced appropriately within the Christian confession. O'Donovan doesn't cite a few verses to prove a point one way or another: he sets out a plan for how the conversation must begin and continue with scripture, and those who read it at variance with one another. The final chapters, "Creation, Redemption, and Nature" and "Good News for the Gay Christian?" are challenging and considerate, and take the reader close to the heart of content of the debate. Part of the anxiety over homosexuality, O'Donovan argues, is the doctrinal revisionism that accompanies the issue [87-88]. The Christian tradition frames its discussion of morals between creation and redemption. O'Donovan envisages in the motif of conversation a mutual exchange of evangelical gifts [118]: hearing this requires much patience, and a willingness to talk.

A Conversation Waiting to Begin deserves a wide and varied audience, and offers several constructive ideas that, despite showing its age in several places, can still be useful and useable now. If nothing else, it pastoral and evangelical concerns come as a timely reminder of how to conduct ourselves Christianly when we disagree.

Michael J Leyden, Liverpool Diocese and Chester University 


\section{Martyn Percy. Shaping the Church: The Promise of Implicit Theology. (Ashgate, 2010)}

Martyn Percy is a prolific author. The strength of his writing lies in his being equally at home in both sociology and theology. Percy deliberately here comes at his study of Anglican Theology as something implicit, in his words, 'the invitation to engage in the exploration of (a theology) centred on the premise that not everything that shapes the church can be or is plainly expressed.'

He develops this approach in the introduction before going on to examine how it might be applied in three key areas: Sacraments - Spiritual Life; Church - the Nature of the Body and Ministry - Practicing Theology. Each of these major sections then looks at three topics. Part 1 (Church) deals with Baptism, Confirmation and Contemporary Eucharistic Practice. In the context of Christian initiation, Percy has some good points to make about the Alpha Courses. He concludes that the implicit theology of Alpha is primarily expressed in its style, not its substance. Sociologically, he contrasts the homely approach of Alpha with the crusading style of Billy Graham. When he comes to examine the ambivalent nature of English religion he quotes some amusing words of the late Basil Hume: 'He had the gift of being able to talk to the English about God without making them wish they were somewhere else.' In part 2 Percy has some penetrating things to say about the contemporary nature of the Anglican Church. In discussing the 'Fresh Expressions' movement, he wonders whether it is actually all that fresh and at one point describes it as 'curiously bourgeois.' Percy devotes a considerable amount of space to questioning the oft-repeated idea that only churches with 'defined boundaries' (mainly Evangelical) are growing numerically. He points to rising numbers attending cathedral services 'where there is patently no relationship between strictness and strength.' He asks the question: 'Is it possible to be religiously tolerant, and yet truly communicate a faith that is life changing? His final answer is 'yes, certainly.' Part 3 tackles the question of ministry. Percy's discussion is wide-ranging and includes the nature of Episcopal ministry and leadership. Is the church an institution or an organisation and thus is the bishop a leader or a manager? I hope this book will become required reading for bishops and indeed for all involved in Christian leadership. His chapter on clergy formation and education is excellent. Percy is clear on the centrality of vocation and hence the purpose of a theological college is 'to integrate the individual character with the catholicity of the office.' Emphatically a college is not 'an Ecclesiastical Boot Camp'! 'Discipleship is a marathon, not a sprint', cautions Percy. Recognising the possibility of 
failure, Percy writes memorably: 'Failure is not the worst thing; letting it utterly defeat you is.' In the final chapter, Percy tackles the difficult issue of conflict and the anger that often results. He sums up the matter briefly thus: 'Anglicanism is born of England, and like its climate, we don't do extremes well.' We prefer coolness or warmth to hot or cold. The handling of strong feelings is a perennial problem for Anglicans and Percy offers sound analysis and advice. He includes a section on the anger expressed by Jesus in the gospels which will repay close study.

In the 1830s, at the height of the Oxford Movement, Thomas Arnold - no friend of the Tractarians - declared: 'The church as now stands, no human power can save.' Percy is more optimistic than that. In his conclusion, he believes that by paying as much attention to the implicit as the explicit, the warring factions can lay down their arms 'to make something richer and stronger.' I hope he's right.

Howard C. Bigg, Cambridge 